\title{
The effects of chrysin on cypermethrin-induced acute intoxication in rainbow trout (Oncorhynchus mykiss)
}

\author{
Ozge Cerit, Feride Koc
}

Received - 14 November 2018/Accepted - 06 June 2019. Published online: 30 June 2019; Inland Fisheries Institute in Olsztyn, Poland Citation: Cerit O., Koc F. 2019 - The effects of chrysin on cypermethrin-induced acute intoxication in rainbow trout (Oncorhynchus mykiss) - Fish. Aquat. Life 27: 102-111.

\begin{abstract}
Cypermethrin (CP) is a toxic insecticide to fishes. Chrysin (CR) is a flavonoid, which can be obtained from plants. The aim of this study was to determine the effects of CR in fishes that had acute CP toxicity. In the study, a total of 60 fishes were used and added to feed and water with CR and CP for 10 days. Blood and tissue samples were collected. The serum enzymes aspartate transaminase (AST) and alanine aminotransferase (ALT), interleukin-1 beta (IL-1 $\beta$ ), interleukin-10 (IL-10), tumor necrosis factor- $\alpha$ (TNF- $\alpha$ ), interleukin-6 (IL-6), and malondialdehyde (MDA), superoxide dismutase (SOD), glutathione peroxidase (GSH-Px), and catalase (CAT) levels/activities were determined for liver and kidneys. In this study, when the CP group was compared to the control group, an increase was observed in the levels/activities of AST, ALT, IL-1ß, TNF- $\alpha$, and IL-6, otherwise, there was a decrease in the IL-10 level in the CP group. Additionally, an increase of MDA levels and a decrease of SOD, GSH-Px, and CAT levels/activities were observed in the $\mathrm{CP}$ group. When the $\mathrm{CP}$ group was compared to the CR groups, there was a decrease in IL-1 $\beta$, IL-6, TNF- $\alpha$, ALT, AST, and MDA levels/activities and there was an
\end{abstract}

\footnotetext{
O. Cerit

Institute of Health Sciences, Veterinary Pharmacology and Toxicology, Erciyes University Kayseri, Turkey

\section{F. Koc [ $\cong]$}

Department of Pharmacology and Toxicology, Faculty of Veterinary Medicine, Erciyes University, Kayseri, Turkey

e-mail: feridekoc@yahoo.com
}

This study is Ozge Cerit's MSc thesis, and was presented as an oral presentation at the ICABB 2017 Congress, Sarajevo, Bosnia. increase, depending on the dosage in GSH-Px, SOD, and CAT levels/activities of the CR groups. In conclusion, CR can prevent tissue damage, affecting oxidation via anti-inflammatory and anti-oxidative effects of acute toxicity of fishes exposed to $\mathrm{CP}$.

Keywords: Antioxidant, fish, chrysin, cypermethrin, cytokine, toxication.

\section{Introduction}

Cypermethrin (CP), a synthetic pyrethroid insecticide, is effective against a wide range of pests in agriculture, public health, and animal husbandry. This agent has a cis and trans isomer structure, and, because of the low vapor of the substance, air accumulation is very low. $\mathrm{CP}$ has low solubility in water, but it is highly soluble in organic solvents. It is a hydrophobic substance, which is slowly hydrolyzed at an acidic $\mathrm{pH}$ but rapidly at a $\mathrm{pH}$ of 9. When $\mathrm{CP}$ is applied to agricultural areas, it accumulates in the soil (with a half-life of 2-4 weeks) and water (with a half-life of about 2 weeks) (WHO 1989). In one study, residue levels of CP in water and hydrosoil samples were investigated, and hydrosoil residues were determined to be approximately $25 \mu \mathrm{g} \mathrm{kg}^{-1}$ and four months later this level was $<9 \mu \mathrm{g} \mathrm{kg}^{-1}$ (Hadfield et al. 1993). In a previous study, the residues of CP were determined in soil (0.001-0.035 $\mu \mathrm{g} \mathrm{g}^{-1}$ ) and in water

\footnotetext{
(c) Copyright by Stanisław Sakowicz Inland Fisheries Institute in Olsztyn.

(C) 2019 Author(s). This is an open access article licensed under the Creative Commons Attribution-NonCommercial-NoDerivs License (http://creativecommons.org/licenses/by-nc-nd/3.0/).
} 
(0.022-0.090 ppb) in India (Kumari et al. 2008). In other study, it was revealed that a $0.695 \mu \mathrm{g} \mathrm{L}{ }^{-1}$ concentration of cypermethrin residue was found in paddy field water and that the river water was contaminated by pesticide residue (Bhattacharjee et al. 2012). CP is transformed into metabolites via hydrolysis and photolysis in soil and water. The main metabolites are 2,2-dimethyl-3-(2,2-dichlorovinyl) cyclopropanecarboxylic acid (CPA) and 3-phenoxybenzoic acid (PBA). This agent and its metabolites cause environmental pollution (WHO 1989).

$\mathrm{CP}$ is a toxic substance that is taken up by organisms through dermal absorption or the gastrointestinal tract. Since CP is lipophilic, it can reach high concentrations in fatty tissues, skin, liver, kidneys, adrenal glands, and ovaries. This insecticide is rapidly metabolized by hydroxylation and ester cleavage and excreted via glucuronate and sulfate in mammals. The toxic effects of $\mathrm{CP}$ are related to the neuronal ion $\left(\mathrm{Na}^{+}\right)$channels. In previous short-term dietary studies, the effects of $\mathrm{CP}$ were neurotoxicity in different species, animals, and target organs, which included liver and kidneys (EFSA 2018). The oral LD50 of CP in rats is $250 \mathrm{mg} \mathrm{kg}^{-1}$ (in corn oil) and 4,123 $\mathrm{mg} \mathrm{kg}^{-1}$ (in water) in rats (Ray 1991, Extoxnet 1996). CP is practically non-toxic in birds and mammals, but it is highly toxic to bees, fish, and other aquatic organisms. The LC50s (96-hour) of CP in bluegill (Lepomis macrochirus Raf.), and rainbow trout (Oncorhynchus mykiss (Walbaum)) is 2.0-2.8 ppb, and $0.82 \mathrm{ppb}$, respectively (Bradbury and Coats 1989). CP is metabolized and eliminated more slowly in fish than in mammals or birds, and can cause high toxicity in fish. The half-life for the elimination of CP in fish is very long (Bradbury and Coats 1989). The bioconcentration factor of CP in rainbow trout is 1,200 times the ambient water concentration. Therefore, it is known that CP is potentially accumulated in aquatic organisms. Residues of CP have been reported in food (fish, meat, milk, and crops) (Majumder and Kaviraj 2017). The Acceptable Daily Intake (ADI) and maximum residue limit (MRL) of cypermethrin are $15 \mu \mathrm{g} \mathrm{kg}^{-1}$ body weight (BW) and $50 \mu \mathrm{g} \mathrm{kg}^{-1}$ BW in Salmonidae (EMEA 2003). CP also inhibits ATPase enzymes in the movement of ions by active transport. Disruption of active transport indicates that $\mathrm{CP}$ is inherently very toxic to aquatic organisms (Siegfried 1993).

The mode of metabolization and action of CP can generate reactive oxygen species (ROS) that induce oxidative stress, or $\mathrm{CP}$ can accumulate in cell membranes and disturb membrane structure because of its hydrophobic characteristic (Muir et al. 1994). In the end, CP can cause serious damage to tissues and organs. To minimize the damage by $\mathrm{CP}$, cells improve their intracellular defense system via antioxidant mechanisms, which act by neutralizing ROS. When CP is taken up by fish, it can increase ROS (Sakin et al. 2011, Gulhan et al. 2012, Kakoolaki et al. 2013, Aldemir et al. 2014) and enzymes (Orun et al. 2014, Al-Ghanim 2014). CP can also lead to immune suppressive (Desi et al. 1986) and inflammatory effects by increasing cytokines (Soliman et al. 2015, Jaiprakash et al. 2018). In previous studies, researchers preferred natural agents to prevent associated oxidative stress and inflammation (Ravipati et al. 2012, Arulselvan et al. 2016). It is reported that allopurinol, vitamin E, and propolis are used as protective agents in fishes exposed to CP (Giray et al. 2001, Gulhan et al. 2012, Kakoolaki et al. 2013, Aldemir et al. 2014). CR, a flavonoid, is one of these protective agents, and it can be obtained naturally from many plants and is present in propolis and some species of mushroom (Mani and Natesan 2018). According to previous studies on CR, it is reported to have anti-carcinogenic (Knowles et al. 2000, Zheng et al. 2003), antioxidant (Pushpavalli et al. 2010, Ciftci et al. 2012), anti-inflammatory (Cho et al. 2004), and antiviral (Critchfield et al. 1996) properties. It is reported that CR can contribute a significant antiproliferative effect related to the decreased amount of ROS (Knowles et al. 2000). It is indicated that $\mathrm{CR}$ contains antioxidant phytochemicals (flavonoids) and reduces oxidative stress in living organisms (Pushpavalli et al. 2010, Ciftci et al. 2012).

Rainbow trout is an important fish species that is rich in $\mathrm{A}$ and $\mathrm{D}$ vitamins and essential unsaturated fatty acids. This type of fish has thin skin, fewer bones, abundant muscle, and is delicious. Because of 
these factors, it is the fish most preferred by people in Turkey (Izci et al. 2009). Rainbow trout is cultured widely because of its ability to adapt rapidly to varying environmental conditions. It contributes the largest share of fish production through aquaculture in Turkey (Aydin and Baltaci 2017). It is reported that liver microsomes of carps are much more able to metabolize pyretroids than those of salmonids (WHO 1989). Therefore, CP can be accumulated in high levels in rainbow trout. These are, therefore, some of the main reasons for choosing this species of fish for the study. Some researchers report that the liver is the main site of detoxification of toxins that enter the body. The liver and kidneys are also related to various metabolic and elimination pathways (Tiwari et al. 2012, Adeyemi et al. 2014, Majumder and Kaviraj 2017). A review of previous studies indicated that the negative effects of CP in fish are reported; however, no studies address the effects of CR on CP-induced acute toxicity in rainbow trout. We hypothesized that $\mathrm{CP}$ is a very toxic agent to fish, and CR might be used as a supplement in fish feed too enhance immunity, and it could be used to prevent oxidative stress and inflammation in this fish species. The aim of the present study was to investigate whether CR prevented tissue damage and anti-inflammatory effects of CP-induced acute toxicity in this fish species.

\section{Material and methods}

\section{Animals}

A total of 60 rainbow trout, weighing 180-220 g, were used in this study. The fish were obtained from a private fish farm (Uzun Yayla, Pýnarbasi, Kayseri). The fish were transferred from the farm to Erciyes University, Veterinary Faculty, Department of Aquatic Products and Diseases, Experimental Research Unit. One week before the experiment at the research unit, the fish were adapted at a suitable temperature $\left(16^{\circ} \mathrm{C}\right)$, under appropriate conditions, with adequate feed. Experiments were performed in accordance with Erciyes University's Experimental
Animal Ethics Committee decision (Ethics Report No: 16/084).

\section{Chemicals and kits}

Cypermethrin (Blotic 7\% EC $500 \mathrm{ml}, 70 \mathrm{mg} \mathrm{mL}^{-1}$, Topkim, İstanbul), chrysin (97\%, Sigma-Aldrich, C2237), Tricaine-S (MS 222, TMS, tricaine methanesulfonate, Western, Washington, USA). IL-1 $\beta$ Fish ELISA kit (Yehua, YHB0049 FI), IL-6 Fish ELISA kit (Yehua, YHB0043 FI), IL-10 Fish ELISA kit (Yehua, YHB0050 FI), TNF- $\alpha$ Fish ELISA kit (Yehua, YHB0038 FI), SOD ELISA kit (Yehua, YHB0018 FI), CAT ELISA kit (Yehua, YHB00 FI), GSH-Px ELISA kit (Yehua, YHB0032 FI), and MDA Colormetric Kit (TBARS, FR40, Oxford Biomed) were obtained from suppliers. It is reported that lethal concentrations of different formulations of $\mathrm{CP}$ in fish are mostly at the nominal concentration of $\mathrm{CP}$ (Majumder and Kaviraj 2017). An emulsified concentrate containing $7 \%$ active ingredient ( $7 \%$ EC) of $\mathrm{CP}$ was formulated based on nominal concentrations of cypermethrin in the water. The study was performed with sub-lethal concentrations of the emulsified concentrate ( $7 \%$ EC) of cypermethrin because this formulation is widely used in agriculture. Cypermethrin (Blotic 7\% EC, $70 \mathrm{mg} \mathrm{mL}^{-1}$ ) was prepared at the rate of $1 / 1000$ for stock solution in water and was added to the fish tanks from this stock solution. The CP concentration of the tanks was $(0.4 \mu \mathrm{g}$ $\mathrm{L}^{-1}$ ) for a day. The rainbow trout were exposed to 0.4 $\mu \mathrm{g} \mathrm{L}^{-1}$ cypermethrin for 10 days.

\section{Experimental design}

The research was performed in 12 tanks $(125 \mathrm{~L}$, fiberglass) with fresh water flow. The trout were divided into 6 groups of 10 fish in each. The experiment was designed to deliver $\mathrm{CR}$ in the feed and to expose the fish to $\mathrm{CP}$ in the water for 10 days. Group 1: Control (non-CR diet was given for 10 days); Group 2: was exposed to $0.4 \mu \mathrm{g} \mathrm{L}^{-1} \mathrm{CP}$; Group 3: $0.4 \mu \mathrm{g} \mathrm{L}^{-1} \mathrm{CP}+\mathrm{CR} 1.25 \mathrm{~g} \mathrm{~kg}^{-1} \operatorname{diet}(\mathrm{CR} 1$ ); Group 4: $0.4 \mu \mathrm{g} \mathrm{L}^{-1} \mathrm{CP}+\mathrm{CR} 2.5 \mathrm{~g} \mathrm{~kg}^{-1} \operatorname{diet}$ (CR2); Group 5: 
CR $1.25 \mathrm{~g} \mathrm{~kg}^{-1}$ diet, and Group 6: CR $2.5 \mathrm{~g} \mathrm{~kg}^{-1}$ diet. Six hours after the last dose (CR), the fish were lightly anesthetized with Tricaine-S (30 $\left.\mathrm{mg} \mathrm{L}^{-1}\right)$. After the fish were anesthetized, $2 \mathrm{~mL}$ of blood was drawn from the caudal vein and tissue samples (liver and kidneys) were collected. Blood samples were centrifuged at $4000 \mathrm{rpm}$ for 10 minutes at $+4^{\circ} \mathrm{C}$, and the serum was removed and transferred to tubes. The serum was stored in a deep freeze $\left(-80^{\circ} \mathrm{C}\right)$ until IL-1 $\beta$, IL-6, IL-10, and TNF- $\alpha$ levels were measured. Some serum was maintained at $+4^{\circ} \mathrm{C}$ to determine the activity of liver function enzymes (ALT, AST). Liver and kidney tissues were stored in a deep freezer $\left(-80^{\circ} \mathrm{C}\right)$ to determine antioxidants (MDA, SOD, CAT, and GSH-Px)

\section{Biochemical tests}

The protein level in tissue was determined according to the method described by Lowry et al. (1951) and modified by Miller (1959). The results are expressed as mg-protein $\mathrm{mL}^{-1}$. For analyses, the liver and kidney tissues of the fish were dissolved and washed with ice-cold, deionized water. Then, one gram of tissue was added to PBS $(7.2 \mathrm{pH})$ at a rate of $1: 10$, and the mixture was homogenized with a homogenizator. The homogenate was centrifuged at 20,000 $\times$ rpm for $1 \mathrm{~h}$ and the supernatant was transferred into Eppendorf tubes for lipid peroxidation analysis. MDA (TBARS), SOD, GSH-Px, CAT, IL-1 $\beta$, IL-6, IL-10, and TNF- $\alpha$ levels were determined according to kit procedures. Measurements were performed on an ELISA (Synergy H1 reader, BioTek) at different wave lengths. Serum ALT and AST levels were measured in accordance with the recommendations of the International Federation of Clinical Chemistry and Laboratory Medicine (IFCC) on a Roche-Hitachi Cobas C 501 system.

\section{Statistical data analyses}

Data are expressed as means \pm standard deviation (SD) in each group. The SPSS statistics program (SPSS, version 21.0, IBM Corp.) was used for statistical evaluations. For statistical analyses, the oxidant and antioxidant enzymes were subjected to one-way ANOVA variance followed by Tukey's range test and were accepted as significant at $\mathrm{P}<0.05$.

\section{Results}

\section{Biochemical results}

Serum ALT and AST activities of the groups are shown in Table 1, which shows that the activities of ALT and AST increased significantly in the CP group when compared with the control group $(\mathrm{P}<0.05)$. Decreased levels of these enzymes were observed in the CP + CR-treated groups when compared to the CP group. The ALT activities of the other groups (1, $3,4,5,6)$ were similar. Changes in ALT activity were significantly higher than those in AST activity in the $\mathrm{CP}$ group. There was no statically significant differences depending on the doses of CR in ALT activity.

Table 1

Effects of the administration of CR and exposure to CP on ALT and AST serum levels and in O. mykiss

\begin{tabular}{lll}
\hline \hline Groups & ALT $(\mathrm{U} / \mathrm{L})$ & AST (U/L) \\
\hline \hline Control & $23.83 \pm 2.78^{\mathrm{a}}$ & $288.40 \pm 58.90^{\mathrm{ab}}$ \\
$\mathrm{CP}$ & $32.66 \pm 3.01^{\mathrm{b}}$ & $535.57 \pm 94.82^{\mathrm{c}}$ \\
$\mathrm{CP}+\mathrm{CR} 1$ & $24.16 \pm 9.47^{\mathrm{a}}$ & $402.66 \pm 64.96^{\mathrm{b}}$ \\
$\mathrm{CP}+$ CR2 & $22.50 \pm 3.44^{\mathrm{a}}$ & $299.33 \pm 48.56^{\mathrm{ab}}$ \\
$\mathrm{CR} 1$ & $20.83 \pm 2.78^{\mathrm{a}}$ & $279.50 \pm 67.73^{\mathrm{a}}$ \\
$\mathrm{CR} 2$ & $20.16 \pm 3.65^{\mathrm{a}}$ & $274.00 \pm 24.15^{\mathrm{a}}$ \\
\hline \hline
\end{tabular}

CP: Cypermethrin $\left(0.4 \mu \mathrm{g} \mathrm{L}^{-1}\right)$, CR1: Chrysin (1.25 $\mathrm{g} \mathrm{kg}^{-1}$ diet), CR2: Chrysin $\left(2.5 \mathrm{~g} \mathrm{~kg}^{-1}\right.$ diet). Data are expressed as means \pm SD. Data in the same column with different letter indexes differ significantly statistically $(\mathrm{P}<0.05)$ 
Table 2

Effects of the administration of CR and exposure to CP on serum levels of interleukin-1 beta (IL-1 $\beta$ ), interleukin-10 (IL-10), tumor necrosis factor- $\alpha$ (TNF- $\alpha$ ), and interleukin-6 (IL-6) in fish

\begin{tabular}{lllll}
\hline \hline Groups & $\mathrm{IL}^{-1} \beta\left(\mathrm{pg} \mathrm{L}^{-1}\right)$ & $\mathrm{IL}-10\left(\mathrm{pg} \mathrm{L}^{-1}\right)$ & TNF- $\alpha\left(\mathrm{ng} \mathrm{L}^{-1}\right)$ & $\left.\mathrm{IL}^{-6}(\mathrm{ng} \mathrm{L})^{-1}\right)$ \\
\hline \hline Control & $85.16 \pm 5.81^{\mathrm{b}}$ & $87.00 \pm 15.27^{\mathrm{b}}$ & $69.66 \pm 6.43^{\mathrm{ab}}$ & $171.50 \pm 12.50^{\mathrm{a}}$ \\
$\mathrm{CP}$ & $117.0 \pm 8.19 \mathrm{~d}$ & $70.16 \pm 4.02^{\mathrm{a}}$ & $90.66 \pm 4.58^{\mathrm{c}}$ & $251.83 \pm 22.76^{\mathrm{c}}$ \\
$\mathrm{CP}+\mathrm{CR} 1$ & $80.33 \pm 7.33^{\mathrm{ab}}$ & $72.33 \pm 4.17^{\mathrm{b}}$ & $203.00 \pm 13.89^{\mathrm{b}}$ \\
$\mathrm{CP}+\mathrm{CR} 2$ & $99.16 \pm 8.90^{\mathrm{c}}$ & $93.00 \pm 5.17^{\mathrm{b}}$ & $65.16 \pm 2.56^{\mathrm{ab}}$ & $192.83 \pm 14.13^{\mathrm{ab}}$ \\
$\mathrm{CR} 1$ & $83.83 \pm 5.23^{\mathrm{b}}$ & $86.16 \pm 5.07^{\mathrm{b}}$ & $65.16 \pm 2.78^{\mathrm{ab}}$ & $172.83 \pm 9.98^{\mathrm{a}}$ \\
$\mathrm{CR} 2$ & $61.16 \pm 2.13^{\mathrm{a}}$ & $89.16 \pm 10.47^{\mathrm{b}}$ & $62.50 \pm 2.73^{\mathrm{a}}$ & $169.00 \pm 7.72^{\mathrm{a}}$ \\
\hline \hline
\end{tabular}

Data are expressed as means \pm SD. Data in the same column with different letter indexes differ significantly statistically $(\mathrm{P}<0.05)$

Table 3

Effects of the administration of CR and exposure to $\mathrm{CP}$ on malondialdehyde (MDA) levels and activities of superoxide dismutase (SOD), glutathione peroxidase (GSH-Px), and catalase (CAT) in O. mykiss liver tissues

\begin{tabular}{|c|c|c|c|c|}
\hline Groups & MDA (nmol mg protein ${ }^{-1}$ ) & SOD (ng mg protein ${ }^{-1}$ ) & GSH-Px (pg mg protein ${ }^{-1}$ ) & CAT (pg mg protein ${ }^{-1}$ ) \\
\hline Control & $1.70 \pm 0.14^{\mathrm{a}}$ & $2.22 \pm 0.46^{\mathrm{b}}$ & $414.33 \pm 10.83^{\mathrm{d}}$ & $101.83 \pm 6.33^{\mathrm{bc}}$ \\
\hline $\mathrm{CP}$ & $4.80 \pm 0.28^{\mathrm{c}}$ & $1.28 \pm 0.24^{\mathrm{a}}$ & $187.66 \pm 17.18^{\mathrm{a}}$ & $80.33 \pm 14.90^{\mathrm{a}}$ \\
\hline $\mathrm{CP}+\mathrm{CR} 1$ & $3.83 \pm 0.27^{b}$ & $1.53 \pm 0.18^{\mathrm{b}}$ & $280.50 \pm 12.43^{b}$ & $84.83 \pm 7.02^{\mathrm{a}}$ \\
\hline $\mathrm{CP}+\mathrm{CR} 2$ & $3.56 \pm 0.17^{b}$ & $2.23 \pm 0.55^{\mathrm{b}}$ & $344.50 \pm 9.22^{\mathrm{c}}$ & $95.66 \pm 6.74^{\mathrm{ab}}$ \\
\hline CR1 & $1.66 \pm 0.15^{\mathrm{a}}$ & $2.29 \pm 0.45^{\mathrm{b}}$ & $396.50 \pm 15.59^{d}$ & $114.33 \pm 6.53^{\mathrm{c}}$ \\
\hline CR2 & $1.33 \pm 0.18^{\mathrm{a}}$ & $2.31 \pm 0.65^{\mathrm{b}}$ & $458.33 \pm 11.94^{\mathrm{e}}$ & $116.00 \pm 8.07^{\mathrm{c}}$ \\
\hline
\end{tabular}

Data are expressed as means \pm SD. Data in the same column with different letter indexes differ significantly statistically $(\mathrm{P}<0.05)$

The AST activity of the CP + CR2 group was similar to the control group. The effects of CR on ALT activity were not dose-dependent.

The IL-1 $\beta$, IL-6, IL-10, and TNF- $\alpha$ levels of all the groups are shown in Table 2 . In the present study, when the $\mathrm{CP}$ group and control group were compared, there were statistically significant increases for IL-1 $\beta$, IL-6, and TNF- $\alpha$ levels, but IL-10 decreased in the $\mathrm{CP}$ group $(\mathrm{P}<0.05)$. When the $\mathrm{CP}+$ CR groups and CP group were compared, the IL-1 $\beta$, IL-6, and TNF- $\alpha$ levels of the fish decreased significantly, but the IL-10 level increased in the CP + CR2 group. The cytokine results of the $\mathrm{CP}+\mathrm{CR} 2$ group did not differ when compared to the controls. The effects of CR were dose-dependent in the groups exposed to the toxin. The differences were statistically significant $(\mathrm{P}<0.05)$.

The MDA, SOD, GSH-Px, and CAT levels/activities of the groups are shown in Table 3 (liver) and Table 4 (kidneys). When comparing the $\mathrm{CP}$ group with the control group, the MDA levels increased significantly, but the SOD, GSH-Px, and CAT levels/activities decreased in the liver tissues of the fish. The differences between the $\mathrm{CP}$ and CR-treated groups $(3,4,5,6)$ were statically significant. The administration of CR decreased MDA levels, but the SOD, GSH-Px, and CAT levels/activities increased statistically significantly in the liver tissues of the fish $(\mathrm{P}<0.05)$. The positive effects of $\mathrm{CR}$ were not dose-dependent for MDA and SOD levels/activities in the liver tissues of the fish.

Table 4 shows the kidney tissues of the fish. The comparison of the $\mathrm{CP}$-induced toxication group with the control group indicated that the MDA levels increased significantly, but SOD, GSH-Px, and CAT levels/activities decreased $(\mathrm{P}<0.05)$. However, when the CP group and CP + CR groups were compared, the differences observed were statistically significant $(\mathrm{P}<0.05)$. The administration of CR decreased MDA levels, but SOD, GSH-Px, and CAT activities increased in the kidney tissues of the fish. The effects of CR were not dose-dependent only for GSH-Px levels, 
Table 4

Effects of the administration of CR and exposure to CP on malondialdehyde (MDA) levels and activities of superoxide dismutase (SOD), glutathione peroxidase (GSH-Px), and catalase (CAT) in O. mykiss kidney tissues

\begin{tabular}{|c|c|c|c|c|}
\hline Groups & MDA (nmol mg protein ${ }^{-1}$ ) & SOD (ng mg protein ${ }^{-1}$ ) & GSH-Px (pg mg protein ${ }^{-1}$ ) & CAT (pg mg protein ${ }^{-1}$ ) \\
\hline Control & $3.58 \pm 0.19^{\mathrm{a}}$ & $2.63 \pm 0.20^{b}$ & $739.33 \pm 11.70^{b}$ & $119.16 \pm 1.70^{b}$ \\
\hline $\mathrm{CP}$ & $7.99 \pm 0.73^{b}$ & $1.85 \pm 0.18^{\mathrm{a}}$ & $474.16 \pm 16.10^{\mathrm{a}}$ & $80.00 \pm 4.80^{\mathrm{a}}$ \\
\hline $\mathrm{CP}+\mathrm{CR} 1$ & $7.51 \pm 0.83^{b}$ & $2.16 \pm 0.32^{\mathrm{a}}$ & $717.83 \pm 11.30^{b}$ & $87.00 \pm 3.83^{\mathrm{a}}$ \\
\hline $\mathrm{CP}+\mathrm{CR} 2$ & $6.98 \pm 0.61^{b}$ & $2.63 \pm 0.07^{\mathrm{b}}$ & $728.66 \pm 15.01^{\mathrm{b}}$ & $121.66 \pm 3.56^{\mathrm{b}}$ \\
\hline CR1 & $3.55 \pm 0.39^{\mathrm{a}}$ & $2.68 \pm 0.19^{b}$ & $774.16 \pm 14.28^{b}$ & $213.66 \pm 1.66^{c}$ \\
\hline CR2 & $2.98 \pm 0.45^{\mathrm{a}}$ & $2.92 \pm 0.24^{b}$ & $881.83 \pm 16.46^{\mathrm{d}}$ & $258.83 \pm 1.33^{\mathrm{d}}$ \\
\hline
\end{tabular}

Data are expressed as means \pm SD. Data in the same column with different letter indexes differ significantly statistically $(\mathrm{P}<0.05)$

but there were related to dose for SOD and CAT activities in kidney tissues. In addition, CR was not affected in the MDA levels of the toxic groups.

\section{Discussion}

Cypermethrin is a very toxic agent in fishes. It has an effect on both glutation and inflammation mechanisms. CR is an antioxidant and anti-inflammatory agent. Previous studies indicated that AST, ALT, and GDH levels were affected in C. carpio exposed to CP (Al-Ghanim 2014). In another study performed by Orun et al. (2014) in rainbow trout, three different sub-lethal doses of CP exposure resulted in increased ALT and AST levels depending on the dose in the toxic groups. In their study on CP exposure in rainbow trout, Velisek et al. (2006) reported that AST activity increased and ALT activity did not change. Borges et al. (2007) reported that in Rhamdia quelen (Quoy \& Gaimard) three different sub-lethal doses of CP resulted in changes of ALT and AST activities depending on both the duration and dose of toxication. A review of studies also indicated that ALT and AST levels increased with CP toxication in all animal species. The current results are consistent with the results of previous studies. Increased ALT activity is known to indicate general hepatocellular injury, while AST activity is known to be indicative of mitochondrial damage (Giannini et al. 2005, Kim et al. 2008). Previous studies also suggest that CP causes liver damage (Velisek et al. 2006,
Borges et al. 2007, Orun et al. 2014). This might be associated with the formation of free radicals that are oxidized by the cytochrome P-450 enzyme system via the effects of CP. It is reported that free radical formation by $\mathrm{CP}$ in the liver results in the inhibition of hepatic ATPase activity; thus, there is necrosis, inflammation, and cytoplasmic hypertrophy in the hepatocytes (Gomaa et al. 2011). It is reported that the inhibition of ATPase activity causes hepatocyte damage because of changes in the active transport of $\mathrm{Na}+, \mathrm{K}+$, and $\mathrm{Ca} 2+$ ions by CP (Jee et al. 2005, Manal et al. 2017). Synthetic pyrethroids are converted to non-stabilized cyanides and aldehydes in the liver. These metabolites might be responsible for cellular damage, decreased ATPase activity, and increased free radicals in the liver (WHO 1989).

In previous studies, it is reported that $\mathrm{CP}$ causes increased enzymes and oxidative stress in fishes (Atamanalp et al. 2002, Jee et al. 2005, Velisek et al. 2006, Borges et al. 2007, Sakin et al. 2011, Gulhan et al. 2012, Kakoolaki et al. 2013, Aldemir et al. 2014, Orun et al. 2014, Al-Ghanim 2014). SOD and GSH are important antioxidants in the intracellular protective mechanism (Chaudière and Ferrari-Iliou 1999, Gutteridge 1995, Birben et al. 2012, Kurutas 2016). MDA is one of the most important indicators of oxidative stress resulting from the peroxidation of polyunsaturated fatty acids (Nielsen et al. 1997). Increasing MDA, GOT (glutamic oxaloacetic transaminase), and GPT (Glutamic pyruvic transaminase) levels/activities in the serum of exposed to CP Sebastes schlegeli (Hilgendorf) was 
reported by Jee et al. (2005). In another study conducted by Gulhan et al. (2012), it was noted that the MDA level increased in rainbow trout that were exposed to $\mathrm{CP}$ at different doses, but the MDA level decreased in $\mathrm{CP}+$ propolis-administered groups. Kakoolaki et al. (2013) reported that CAT activity decreased and MDA level increased in a CP-induced group compared to the control group in fish brains. In the $\mathrm{CP}+$ propolis-treated group compared to the CP group, CAT activity increased and MDA level decreased. Aldemir et al. (2014) reported that CAT activities and MDA levels increased in fish exposed to $\mathrm{CP}$ compared to the control group and that CAT activities and MDA levels decreased in the $\mathrm{CP}+$ propolis group compared to the $\mathrm{CP}$ group. Sakin et al. (2011) reported that CP caused oxidative stress. When the CP-exposed group was compared with the control group, the level of MDA increased significantly, while the activities of CAT, GSH, and GSH-Px decreased significantly in the rainbow trout group exposed to CP. Our results are similar to previous studies in fish and other animals that exposed to CP (Jee et al. 2005, Sakin et al. 2011) and propolis-treated in fishes exposed to CP (Gulhan et al. 2012, Kakoolaki et al. 2013, Aldemir et al. 2014).

The effect of CP on lipid peroxidation can be either direct or indirect because of its hydrophobic structure. CP can induce oxidative stress and, as a hydrophobic compound, it can accumulate in cell membranes and disturb their structures. Impaired membrane structure can result from free radical formation by inducing oxidative stress (Muir et al. 1994). In addition, this indirect mechanism can also contribute to changes in ion transport in cell membranes from ATPase inhibition. A review of past studies indicated that many antioxidant substances were used to protect against the adverse effects of CP in many fish species (Giray et al. 2001, Gulhan et al. 2012, Kakoolaki et al. 2013, Aldemir et al. 2014). Flavonoids, such as propolis, have been shown to have antioxidant effects by inhibiting xanthine oxidase and influencing flavonoids in superoxide anion radicals (Borges et al. 2007, Kakoolaki et al. 2013). CR, an important flavonoid, is a high-level substance in propolis, and it can reduce free radical formation by inhibiting xanthine oxidase. Therefore, CR can prevent oxidative stress.

Cytokines are hormone-like proteins produced by various cell types (macrophages and $\mathrm{T}$ cells), and they play a role in the formation of immune and inflammatory responses. In addition, microbial products such as lipopolysaccharide can also secrete their own cytokines by direct stimulation of mononuclear phagocytes. According to their main effects, cytokines are divided into subgroups. TNF is secreted especially from microorganisms, particularly macrophages, $\mathrm{T}$ cells, active NK cells, and active mast cells, which are activated in response to the lipopolysaccharides of gram-negative bacteria. TNF is an important mediator and provides neutrophil and macrophage adhesion in infected sites by stimulating endothelial cells. TNF also affects the hypothalamus in fever formation and facilitates acute phase protein production. There are two types of TNF: TNF- $\alpha$, is released from active macrophages, and TNF- $\beta$ (lymphotoxin) is released from active T cells. IL-1 is an inflammatory cytokine produced by activated macrophages. It is similar to TNF- $\alpha$ in terms of effectiveness and helps to activate $\mathrm{T}$ cells. IL-6 is synthesized by mononuclear phagocytes, vascular endothelial cells, fibroblasts, epithelial cells, and some active $\mathrm{T}$ cells. The most prominent effects of IL-6 are on hepatocytes and B lymphocytes. Il-6 causes a release of immunoglobulin from B lymphocytes, acts as a growth factor for B lymphocytes, and leads to the synthesis of many plasma proteins by hepatocytes. These proteins contribute to the acute phase response in inflammation. IL-10 is produced by some active B cells, TH cells, active macrophages, and some non-lymphocytic cell types (keratinocytes). This cytokine has an effective inhibitor, and this effect results in a reduction of the immune response. IL-10 has two important effects. Firstly, it inhibits the production of cytokines (TNF- $\alpha$, IL-1, IL-12, chemokine) by macrophages and the secondly, it can prevent functions of macrophages in T cell activation. TNF- $\alpha$, IL- $1 \beta$, and IL-6 are pro-inflammatory cytokines and IL-10 is known as an anti-inflammatory cytokine (Guner et al. 1997). 
A review of the literature on CP-toxication in fish revealed no studies on cytokine levels in fish. However, Soliman et al. (2015) reported that sesame oil (SO) was used against CP-toxication rats. Albumin, urea, creatinine, GPT, GOT, lipid profiles, IL-1 $\beta$, IL-6 levels, and TNF- $\alpha$ mRNA expression increased, but CAT, SOD, GST levels, and IL-10 mRNA expression decreased in the $\mathrm{CP}$ group compared to the control. Co-administration of SO with $\mathrm{CP}$ normalized these biochemical changes. CP-induced degeneration produces changes in kidney and liver tissues that are ameliorated by SO. The current study results are consistent with those found in the literature (Soliman et al. 2015).

There might be interactions during excretions between CP and CR. Namely, CR has an inductive effect on enzyme (UDP-glucosylic acid) synthesis (Walle et al. 2000). CP can be eliminated as inactive metabolites via glucuronic acid coupling reactions (Edwards et al. 1987). This enzyme can increase with the use of CR, thus increased enzyme can increase the metabolism and excretion of CP.

In conclusion, the results of the current study showed that CP stimulates oxidation and inflammation in fishes. Administering CR contributed to antioxidant activity by the inhibition of free radicals, increased antioxidant enzymes, and reduced inflammation via the decrease of cytokines in $\mathrm{CP}$-induced toxicity in fish. In the future, if CR-supplemented fish food is used in fish farming, it might be beneficial in enhancing antioxidant capacity and anti-inflammatory effects. CR is recommended as an immunity enhancer agent in fish.

Acknowledgments. This study was supported by the Scientific Research Council of Erciyes University, Kayseri, TURKEY (Project no: TYL-2017-7303).

Autor contributions. F.K. designed the research; O.C. and F.K performed the research and wrote the paper.

\section{References}

Adeyemi J.A., Adewale O.O., Oguma A.Y. 2014 - Mortality, oxidative stress and hepatotoxicities in juvenile African catfish, Clarias gariepinus Burchell, exposed to lead and cypermethrin - Bull. Environ. Contam. Toxicol. 92: 529-533

Aldemir O.S., Talas Z.S., Gulhan M.F., CakĄr O., Ozdemir I., Dastan S.D., Dogan H. 2014 - Role of propolis on oxidative stress in various tissues of fish - Fresen. Environ. Bull. 23: 1-5.

Al-Ghanim K.A. 2014 - Effect of cypermethrin toxicity on enzyme activities in the freshwater fish Cyprinus carpioAfr. J. Biotechnol. 13: 1169-1173.

Arulselvan P., Fard M.T., Tan W.S., Gothai S., Fakurazi S., Norhaizan M.E., Kumar S.S. 2016 - Role of Antioxidants and Natural Products in Inflammation - Oxid. Med. Cell. Longev. 13: 1-15.

Atamanalp M., Yanik T., Haliloglu H.I., Sitki A. 2002 - Alterations in the haematological parameters of rainbow trout, Oncorhynchus mykiss, exposed to cypermethrin - Isr. J. Aquacult. Bamidgeh. 54: 99-103.

Aydin H., Baltaci M.A. 2017 - The place of Istanbul University Sapanca Inland Waters Research and Application Unit in the spread of trout production in Turkey - Turk. J. Aqua. Sci. 32: 129-134 (in Turkish).

Bhattacharjee S., Fakhruddin A.N.M., Chowdhury M.A.Z., Rahman M.A., Alam M.K. 2012 - Monitoring of Selected Pesticides Residue levels in water samples of paddy fields and removal of cypermethrin and chlorpyrifos residues from water using rice bran - Bull. Environ. Contam. Toxicol. 89: 348-353.

Birben E., Sahiner U.M., Sackesen C., Erzurum S., Kalayci O. 2012 - Oxidative stress and antioxidant defense - World Allergy Organ. J. 5: 9-19.

Borges A., Scotti L.V., Siqueira D.R., Zanini R., Amaral F., Jurinitz D.F., Wassermann G.F. 2007 - Changes in $\underline{\text { hematological and serum biochemical values in jundiá }}$ Rhamdia quelen due to sub-lethal toxicity of cypermethrin - Chemosphere 69: 920-926.

Bradbury S.P., Coats J.R. 1989 - Toxicokinetics and toxicodynamics of pyrethroid insecticides in fish - Environ. Toxicol. Chem. 8: 373-380.

ChaudiPre J., Ferrari-Iliou R. 1999 - Intracellular antioxidants: from chemical to biochemical mechanisms - Food. Chem. Toxicol. 37: 949-962.

Cho H., Yun C.W., Park W.K., Kong J.Y., Kim K.S., Park Y,, Lee S., Kim B.K. 2004 - Modulation of the activity of pro-inflammatory enzymes, COX-2 and iNOS, by chrysin derivatives - Pharmacol. Res. 49: 37-43.

Ciftci O., Ozdemir I., Aydin M., Beytur A. 2012 - Beneficial effects of chrysin on the reproductive system of adult male rats - Andrologia 44: 181-186.

Critchfield J.W., Butera S.T., Folks T.M. 1996 - Inhibition of HIV activation in latently infected cells by flavonoid compounds - AIDS Res. Hum. Retroviruses 12: 39-46.

Desi I., Dobronyi I., Varga L. 1986 - Immuno-, neuro-, and general toxicologic animal studies on a synthetic 
pyrethroid: cypermethrin - Ecotoxicol. Environ. Saf. 12: 220-232.

Edwards R., Millburn P., Hutson H. 1987 - The toxicity and metabolism of the pyrethroids cis and trans-cypermethrin in rainbow trout, Salmo gairdneri Xenobiotica 17: 1175-1193.

EFSA 2018 - Peer review of the pesticide risk assessment of the active substance cypermethrin - EFSA Journal, 16: 5402. https://doi.org/10.2903/j.efsa.2018.5402.

EMEA 2003 - The European Agency for the Evaluation Medicinal Products- Cypermethrin-Salmonidae EMEA/MRL/861/03-FINAL.

Extoxnet 1996 - Extension Toxicology Network, Pesticide Information Profiles http://extoxnet.orst.edu/pips/ cypermet.htm

Giannini E.G., Testa R., Savarino V. 2005 - Liver enzyme alteration: a guide for clinicians - Can. Med. Assoc. J. 172: 367-379.

Giray B., Gürbay A., Hincal F. 2001 - Cypermethrin-induced oxidative stress in rat brain and liver is prevented by vitamin E or allopurinol - Toxicol. Lett. 118: 139-146.

Gomaa M.S., Abd Alla M.A., Sameer M.M. 2011 - The possible protective effect of propolis (bee glue) on cypermethrin-induced hepatotoxicity in adult albino rats - Mansoura J. Forensic. Med. Clin. Toxicol. 19: 17-32.

Gulhan FM., Duran A., Selamoglu T.Z., Kakoolaki S., Mansouri SM. 2012 - Effects of propolis on microbiologic and biochemical parameters of Rainbow trout (Oncorhynchus mykiss) after exposure to the pesticide - Iran. J. Fish. Sci. 11: 490-503.

Gutteridge J.M. 1995 - Lipid peroxidation and antioxidants as biomarkers of tissue damage - Clin. Chem. 41: 1819-1828.

Guner I., Ozmen D., Bayindir O. 1997 - Cytokines - Turkiye Klinikleri. J. Med. Sci. 17: 65-74 (in Turkish).

Hadfield S.T., Sadler J.K, Bolygo E., Hill S., Hill I.R. 1993 Pyrethroid residues in sediment and water samples from mesocosm and farm pond studies of simulated accidental aquatic exposure - Pestic. Sci. 38: 283-294.

Izci L., Gunlu A., Bilgin G. 2009 - Utilization manner of Raibow trout (Oncorhynchus mykiss, Walbaum 1792) in Turkiye - Süleyman Demirel Üniversitesi, Eğirdir Su Ürünleri Fakültesi Dergisi 5: 73-79 (in Turkish).

Jaiprakash V.Y., Somesh B., Reddy D.N.S., Malampati R. 2018 - Influence of deltamethrin and cypermethrin on the expression of SUMO isoforms and UBC9 - Pol. J. Environ. Stud. 27: 1401-1406.

Jee J.H., Masroor F., Kang J.C. 2005 - Responses of cypermethrin linduced stress in haematological parameters of Korean rockfish, Sebastes schlegeli (Hilgendorf) Aqua. Res. 36: 898-905.

Kakoolaki S., Talas Z.S., Cakir O., Ciftci O., Ozdemir I. 2013 Role of propolis on oxidative stress in fish brain - Basic. Clin. Neurosci. 4: 153-158.
Kim W.R., Flamm S.L., Di Bisceglie A.M., Bodenheimer H.C. 2008 - Serum activity of alanine aminotransferase (ALT) $\underline{\text { as }}$ an indicator of health and disease - Hepatology 47: 1363-1370.

Knowles L.M., Zigrossi D.A., Tauber R.A., Hightower C., Milner J.A. 2000 - Flavonoids suppress androgen-independant human prostate tumor proliferation Nutr. Cancer. 38: 116-122.

Kumari B., Madan V.K., Kathpal T.S. 2008 - Status of insecticide contamination of soil and water in Haryana, India Environ. Monit. Assess. 136: 239-244.

Kurutas E.B. 2016 - The importance of antioxidants which play the role in cellular response against oxidative/nitrosative stress: current state - Nutr. J. 15: 71, doi:10.1186/s12937-016-0186-5.

Lowry O.H., Rosebrough N.J., Farr A.L., Randal R.J. 1951 Protein measurement with the folin phenol reagent - J. Biol. Chem. 193: 265-275.

Majumder R., Kaviraj A. 2017 - Cypermethrin induced stress and changes in growth of freshwater fish Oreochromis niloticus - Int. Aqua. Res. 9: 117-128.

Manal A.H., Nadia M., Abd El Mawgoud A.A.A., Lila M. 2017 Cypermethrin-induced histopathological, ultrastructural and biochemical changes in liver of albino rats: The protective role of propolis and curcumin Beni-Suef Univ. J. Basic Appl. Sci. 6: 160-173.

Mani R., Natesan V. 2018 - Chrysin: Sources, beneficial pharmacological activities, and molecular mechanism of action - Phytochemistry 145: 187-196.

Miller G.L. 1959 - Protein determination for large numbers of samples - Anal. Chem. 31: 964.

Muir D.C.G., Hobden B.R., Servos M.R. 1994 Bioconcentration of pyrethroid insecticides and DDT by rainbow trout: uptake, depuration, and effect of dissolved organic carbon - Aquat. Toxicol. 29: 223-240.

Nielsen F., Mikkelsen B.B., Nielsen J.B., Andersen H.R., Grandjean P. 1997 - Plasma malondialdehyde as biomarker for oxidative stress: reference interval and effects of life-style factors - Clin. Chem. 43: 1209-1214.

Orun I., Selamoglu T., Gulhan M.F., Erdogan K. 2014 - Role of propolis on biochemical and hematological parameters of Oncorhynchus mykiss exposed to cypermethrin - J. Survey. Fish. Sci. 1: 21-35.

Pushpavalli G., Kalaiarasi P., Veeramani C., Pugalendi K.V. 2010 - Effect of chrysin on hepatoprotective and antioxidant status in D-galactosamineinduced hepatitis in rats Eur. J. Pharmacol. 631: 36-41.

Ravipati A.S., Zhang L., Koyyalamudi S.R., Jeong S.C., Reddy N., Bartlett J., Smith P.T., Shanmugam K., Münch G., Wu M.J., Satyanarayanan M., Vysetti B. 2012 - Antioxidant and anti-inflammatory activities of selected Chinese medicinal plants and their relation with antioxidant content - BMC Complement. Altern. Med. 12: 173. 
Ray D.E. 1991 - Pesticides derived from plants and other organisms - In: Handbook of Pesticide Toxicology Classes of Pesticides - Vol. 2 (Eds) W.J. Hayes, E.R. Laws, Academic Press, San Diego, California: 585-636.

Sakin F., Ispir U., Yonar S.M., Yonar M.E., Taysi M.R. 2011 Effect of short-term cypermethrin exposure on oxidant-antioxidant balance in the whole body of rainbow trout fry - Fresen. Environ. Bull. 20: 2806-2809.

Siegfried B.D. 1993 - Comparative toxicity of pyrethroid insecticides to terrestrial and aquatic insects - Environ. Toxicol. Chem. 12: 1683-1689.

Soliman M.M., Attia H.F., El-Ella G.A. 2015 - $\underline{\text { Genetic and }}$ histopathological alterations induced by cypermethrin in rat kidney and liver: protection by sesame oil - Int. J. Immunopathol. Pharmacol. 28: 508-520.
Tiwari S., Tiwari R., Singh A. 2012 - Impact of cypermethrin on fingerlings of common edible carps (Labeo rohita) Sci. World J. Article ID 291395. doi: 10.1100/2012/291395

Velisek J., Wlasow T., Gomulka P., Svobodova Z., Dobsikova R., Novotny L., Dudzik M. 2006 - Effects of cyperhethrin on rainbow trout (Oncorhynchus mykiss) - Vet. Med. 51: 469-476.

Walle T., Otake Y., Galijatovic A., Joseph K., Walle U.K. 2000 - Induction of UDP-glucuronosyltransferase UGT1A1 by the flavonoid chrysin in the human hepatoma cell line Hep G2 - Drug. Metab. Dispos. 28: 1077-1082.

WHO 1989 - World Health Organization. Cypermethrin Environmental Health Criteria (EHC) 82. International Programme on Chemical Safety, Geneva, Switzerland.

Zheng X., Meng W.D., Xu Y.Y., Cao J.G., Qing F.L. 2003 Synthesis and anticancer effect of chrysin derivatives Bioorg. Med. Chem. Lett. 13: 881-884. 